DOI: $10.2478 / \mathrm{v} 10129-010-0006-6$

\author{
Agnieszka Dobrzycka ${ }^{1}$, Zbigniew Broda $^{1}$, Jan Bocianowski $^{2}$, Anna Ćwiklinska ${ }^{1}$ \\ ${ }^{1}$ Department of Genetics and Plant Breeding, Poznań University of Life Sciences, Poznań, Poland, \\ ${ }^{2}$ Department of Mathematical and Statistical Methods, Poznań University of Life Sciences, Poznań, Poland
}

\title{
USE OF AFLP MOLECULAR MARKERS FOR ESTIMATING GENETIC SIMILARITY OF ALFALFA (MEDICAGO SATIVA L. SL.)
}

\begin{abstract}
The aim of study was to determine genetic similarity among sixteen alfalfa populations using the AFLP technique. Plant material was selected considering the high genotypic variability. It included populations of different origin: native forms of alfalfa (secondary ecotypes), inbred lines, single hybrids, synthetic populations, varieties and mutants. Analysis was carried out using 10 combinations of primers. It was noticed, that in case of the studied alfalfa populations, the highest polymorphism was obtained using primers with three selective nucleotides. The genetic similarity coefficients were calculated by the method of Nei and Li. Those coefficients were used for the hierarchical grouping of objects by the unweighted pair group method of arithmetic means. Results of the grouping were presented in the form of dendrogram. Values of coefficients ranged from 0.3311 (between the inbred F line and the Ulstar variety) to 0.8076 (between ecotype 27 and the synthetic population Syn 7-3). Dendrogram of genetic similarity obtained in this way did not fully correspond with the known data about the studied populations' origin. Considering the genetic similarity, inbreed line F was the most outlying from the studied populations of alfalfa.
\end{abstract}

Key words: AFLP markers, alfalfa, diversity, genetic similarity

\section{INTRODUCTION}

Alfalfa is one of the most important perennial fodder plants supplying the greatest amounts of dry and green biomass as well as protein from one ha. Protein obtained from alfalfa is characterized by a very favourable composition - it is rich in exogenous aminoacids. Being a perennial plant with very deeply penetrating root system, it plays a structure-creating role exerting an influence on soil fertility and improving its structure. Its deeply reaching root system causes translocation of nutritive soil components from the deeper layers to the shellower ones. Being a papilionaceous plant, alfalfa enriches soil with nitrogen thanks to its symbiosis with nodule bacteria (Rhizobium meliloti). Among the postharvest remains in the soil, $80 \%$ of them consist of roots which contain 90-120 kg N/ha (Staszewski 1975).

Communicated by Edward Arseniuk 
In the climatic conditions of Poland, there appear many problems connected with seed setting and with alfalfa fecundity. Alfalfa belongs to thermophilous plants originating from south-western Asia, hence the poor setting of pods and seeds may be the result of weather conditions characteristic of Polish climate: lower temperature, shorter time of insolation, as well as an unfavourable distribution of rainfalls in the blooming period. Poor setting of pods and seeds may be also caused by the properties of the particular alfalfa genotype (Julier et al. 1995).

It seems justified to look for genotypes which are adapted to local climatic conditions, or which do not react with a significant decrease in their seed yield. Such genotypes could be also utilized in breeding of this species in order to obtain varieties with an increased seed setting ability. However, it is known that an excessive genetic distance between the components used in the crossings may cause difficulties in obtaining hybrids.

Molecular markers are widely used in many species (Bachmann 1994, Staub et al. 1996), including many papilionaceous plants: alfalfa (Medicago sativa) (Yu and Pauls 1993); red clover (Trifolium pratense) (Kongkiatingam et al. 1996) and white clover (Trifolium repens) (Gustine and Huff 1999).

Among the great number of actually available molecular techniques (Rafalski et al. 1996, Staub et al. 1996), the AFLP (Amplified Fragment Length Polymorphism) technique (Vos et al. 1995) is especially useful in the studies on genetic variability. This technique combines digestion with restrictive enzymes with PCR (Polymerase Chain Reaction). Enzymes generate „sticky ends" which are joined by 20-30 nucleotide fragments (adapters). Then, reaction of pre-amplification is carried out and it is followed by specific amplification. These markers show a wide polymorphism, sometimes, it is possible to distinguish homo- and heterozygotes by the estimation of band intensity. A merit of AFLP markers is the fact that they generate a significantly greater number of differentiating bands than the RAPD markers, permitting a more precise estimation of genetic similarity. Furthermore, in case of AFLP markers, there is no problem with result repeatability which is frequently observed in case of RAPD markers (Jones et al. 1997).

The objective of the presented paper was the determination of the genetic similarity between sixteen alfalfa populations of diversed origin by using the AFLP (Amplified Fragment Length Polymorphism) technique.

\section{MATERIAL AND METHODS}

Plant material included 16 populations of alfalfa (Medicago sativa L. sl.), originating from the collection of the Department of Plant Genetics and Breeding, University of Life Sciences in Poznań (Poland). Populations for studies were selected regarding the wide genetic differentiation, therefore, they included ecotypes, registered varieties, inbred lines, synthetic populations and mutants. Examinated populations are shown in Table 1. 
Alfalfa populations examinated in conducted studies.

\begin{tabular}{|c|c|c|}
\hline Genotype & Origin/Genetic composition & Characteristic \\
\hline Ecotypes 12 and 27 & Poznań, Poland & $\begin{array}{l}\text { Local ecotypes, wildly occurring on } \\
\text { the area of Poznan, adapted to the } \\
\text { local climatic conditions }\end{array}$ \\
\hline Inbred lines: & & $\begin{array}{l}\text { Cultivated from hybrids obtained in } \\
\text { result of crossing alfalfa varieties } \\
\text { originating from the USA, France, } \\
\text { Sweden (Svalöf), domestic forms } \\
\text { and wild forms of Medicago falcata. } \\
\text { After selection, these lines were } \\
\text { cultivated using inbred cultivation } \\
\text { to the S5 generation }\end{array}$ \\
\hline - F line & $\begin{array}{l}\text { Cultivated from the crossing of } \\
\text { the following varieties: Du } \\
\text { Puits, Vernal, wild forms of } M \text {. } \\
\text { falcata species and local } \\
\text { ecotypes }\end{array}$ & \\
\hline - B10 line & $\begin{array}{l}\text { Cultivated from the crossings } \\
\text { of Vernal variety, local } \\
\text { ecotypes and alfalfa families } \\
\text { originating from Svalöf }\end{array}$ & \\
\hline
\end{tabular}

Single hybrids:

$\begin{array}{ll}-\mathrm{F} \times \mathrm{B} 10 & \begin{array}{l}\text { Single hybrid between F line } \\ \text { and B10 line }\end{array} \\ -\mathrm{B} 10 \times \mathrm{F} & \begin{array}{l}\text { Single hybrid between F line } \\ \text { and B10 line }\end{array}\end{array}$

Synthetic populations:

Inbred lines D5, E1/2, G1/1

$$
\text { - Syn 9-3 }
$$

Inbred lines E1/2, G9/1, F1

\section{$\mathrm{F}$ line was the maternal form}

B10 line was the maternal form

Created from inbred S5 lines with the highest specific combination ability

Inbred lines used as components for the creation of synthetic populations were cultivated from the following materials:

- D line - Du Puits variety, alfalfa families from Svalöf, Medicago media, local ecotypes.

- E line - Medicago media, Du Puits variety, Kleszczewska variety, families of alfalfa from Svalöf.

- G line - Medicago media, alfalfa families from Svalöf, local ecotypes. 


\section{Continued}

Table 1

\begin{tabular}{|c|c|c|}
\hline Genotype & Origin/Genetic composition & Characteristic \\
\hline \multicolumn{3}{|l|}{ Mutants: } \\
\hline - 'tf' mutant & $\begin{array}{l}\text { Spontaneous mutants with a } \\
\text { variable inflorescence structure } \\
\text { which appeared in the population } \\
\text { of plants obtained from crossings } \\
\text { of Radius variety and French } \\
\text { genotypes with normal flowers }\end{array}$ & $\begin{array}{l}\text { Defined as plants with 'tf" gene } \\
\text { (top flowering). The top flowering } \\
\text { plants are characterized by a } \\
\text { shorter and more balanced period } \\
\text { of blooming and a greater number } \\
\text { of racemes on flower shoots }\end{array}$ \\
\hline - 'br' mutant & $\begin{array}{l}\text { S2 line of mutants containing 'br' } \\
\text { gene (branch raceme) }\end{array}$ & $\begin{array}{l}\text { Plants characterized by a branched } \\
\text { flower torus resembling a panicle }\end{array}$ \\
\hline - 'lp' mutant & $\begin{array}{l}\text { S1 line of plants contain 'lp' gene } \\
\text { (long peduncle) }\end{array}$ & $\begin{array}{l}\text { Plants characterized by an } \\
\text { elongated flower torus which make } \\
\text { that the raceme is longer and there } \\
\text { is a greater number of flowers in } \\
\text { the racemes }\end{array}$ \\
\hline Ulstar & $\begin{array}{l}\text { Synthetic variety with a long } \\
\text { raceme, cultivated from the 'lp' } \\
\text { mutant and from Radius variety }\end{array}$ & Contains 'lp' gene \\
\hline Vernal & USA & $\begin{array}{l}\text { American arable crop with high } \\
\text { durability (up to } 25 \text { years). This } \\
\text { variety shows poor } \\
\text { winter-hardness, after three years } \\
\text { of use, it drops out. It is very well } \\
\text { leaved }\end{array}$ \\
\hline Du Puits & France & $\begin{array}{l}\text { French variety, the so called big } \\
\text { Flemish type with a significant } \\
\text { share of leaves. In Poland, its } \\
\text { fecundity is small }(4-12 \%) \text {. It } \\
\text { shows a poor winter-hardness and } \\
\text { medium frost-resistance; its mean } \\
\text { seed yield is } 27-30 \mathrm{~kg} / \text { ha }\end{array}$ \\
\hline Sitel & European variety & $\begin{array}{l}\text { Variety of Flemish type - classical } \\
\text { Medicago sativa. It is a deceptive } \\
\text { variety because it is sensitive to } \\
\text { cold; when frosts last longer, it } \\
\text { drops out already in the first year } \\
\text { of growing }\end{array}$ \\
\hline Radius & Poland & $\begin{array}{l}\text { Variety obtained by way of } \\
\text { selection among the following } \\
\text { variety hybrids: Warminska, } \\
\text { Europe, Du Puits. The varieties } \\
\text { were subjected to low temperatures } \\
\text { and selection was done regarding } \\
\text { the length of flower torus. They are } \\
\text { characterized by good pod and } \\
\text { seed setting. They represent plants } \\
\text { of generative habit }\end{array}$ \\
\hline
\end{tabular}

Plant material for molecular studies was sampled from plants grown in a greenhouse. DNA isolation was carried out using Dneasy ${ }^{\text {TM }}$ Plant Mini Kit of QIAGEN ${ }^{\circledR}$ Co. All DNA samples were brought to the concentration 
of $2500 \mu \mathrm{g} / \mathrm{ml}$. Bulked samples representing examined populations were prepared from plant material obtained from 10 single plants.

AFLP analysis was carried out in the following way: isolated genomic DNA was subjected to digestion by restrictive enzymes EcoRI and MseI. During digestion, samples were incubated for $3 \mathrm{hrs}$ at $37^{\circ} \mathrm{C}$ and 15 minutes at $70^{\circ} \mathrm{C}$. Subsequently, ligation (i.e. connection of adapters) was carried out and preamplification was performed (lasting for 20 cycles, according to the following program: denaturation $\left(94^{\circ} \mathrm{C}\right)$ - 30 seconds; annealing $\left(56^{\circ} \mathrm{C}\right)$ 60 seconds; amplification $\left(72^{\circ} \mathrm{C}\right)$ - 60 seconds. Selective amplification was carried out in $20 \mu \mathrm{l}$ of mixture including the diluted DNA matrix (after pre-amplification), the EcoRI and MseI primers, deionized water, dNTP, PCR buffer $10 \times, \mathrm{MgCl}_{2}$, Taq polymerase. Samples were placed in a thermocycler with the following program: the first 2 cycles - denaturation $\left(94^{\circ} \mathrm{C}\right)-1$ minute, annealing $\left(65^{\circ} \mathrm{C}\right)-1$ minute, amplification $\left(72^{\circ} \mathrm{C}\right)-2$ minutes; successive 9 cycles - the amplification temperature was decreased in each cycle by $1^{\circ} \mathrm{C}$, then there followed successive 35 cycles: denaturation $\left(94^{\circ} \mathrm{C}\right)-1$ minute, annealing $\left(56^{\circ} \mathrm{C}\right)-1$ minute, amplification $\left(72^{\circ} \mathrm{C}\right)$ -2 minutes. In following analysis, primers with three and four selective nucleotides were used, but using only the first primers a satisfactory level of polymorphism has been reached.

The electrophoresis of amplification products was carried out on 5\% polyacrylamide gel in $1 \mathrm{M} \mathrm{TBE}$ for 2.5 hours at $2400 \mathrm{~V}$ and $400 \mathrm{~mA}$ intensity. After the termination of electrophoresis, the gel was coloured with silver nitrate and sodium carbonate. After the colouring of bands, they were fixed with acetic acid, then the gel was rinsed in distilled water and dried in a vacuum drier.

After the analysis, the polymorphic bands were summed up. The coefficients of genetic similarity (GS) were calculated using the formula by Nei and $\operatorname{Li}(1979)$ :

$$
G S_{A B}=\frac{2 \times N_{A B}}{\left(N_{A}+N_{B}\right)}
$$

where: $\mathrm{N}_{\mathrm{AB}}$ is the number of alleles present both in object $A$ and in object $\mathrm{B}, \mathrm{N}_{\mathrm{A}}$ - the number of alleles present in object $\mathrm{A}, \mathrm{N}_{\mathrm{B}}$ - the number of alleles present in object $\mathrm{B}$.

Those coefficients were used for the hierarchical grouping of objects by the unweighted pair group method of arithmetic means. Results of the grouping are presented in the form of dendrogram. All statistical calculations were performed using GenStat v. 7.1 (Payne et al. 2003). 


\section{RESULTS}

Out of 25 tested primer combinations 10 generated a high polymorphism and on their basis, the genetic similarity was estimated (Table 2).

\begin{tabular}{|c|c|c|c|}
\hline \multicolumn{4}{|c|}{$\begin{array}{l}\text { Characteristics of amplification's products generated by used combinations } \\
\text { of primers in AFLP technique }\end{array}$} \\
\hline Primers' combination & $\begin{array}{l}\text { Number of all polymorphic } \\
\text { DNA products }\end{array}$ & Number of bands per lane & $\begin{array}{l}\text { Size of DNA fragments } \\
{[\mathrm{bp}] \mathrm{min}-\max }\end{array}$ \\
\hline E-AGG/M-CAA & 44 & 18.0 & $104-775$ \\
\hline E-ACT/M-CTC & 54 & 15.9 & $103-550$ \\
\hline E-ACC/M-CTC & 42 & 16.7 & $104-810$ \\
\hline E-ACC/M-CTA & 60 & 21.7 & $100-1000$ \\
\hline E-ACA/M-CTA & 64 & 27.6 & $100-505$ \\
\hline E-AGC/M-CAA & 64 & 29.9 & $100-875$ \\
\hline E-AGC/M-CTC & 53 & 16.9 & $102-100$ \\
\hline E-ACT/M-CTA & 70 & 27.0 & $100-1400$ \\
\hline E-ACA/M-CAA & 32 & 12.1 & $121-600$ \\
\hline E-AGG/M-CTC & 48 & 18.5 & $113-785$ \\
\hline
\end{tabular}

The tested primers' combinations generated from 32 to 70 polymorphic products (Table 2). Totally for all the primers and populations 531 bands were obtained, and on this basis dendrogram of genetic similarity was created. Maximal number of polymorphic fragments was generated by the primers E-ACT/M-CTA - 70. The least number of polymorphic products was generated by primers E-ACA/M-CAA - 32. The highest mean number of polymorphic fragments per one population was obtained for the primer pair E-AGC/M-CAA - 29.9, while the lowest number for the combination E-ACA/M-CAA-12.1 of product per one lane. The molecular mass of the obtained fragments oscillated from 100 to 1400 base pairs.

Genetic similarity of the studied alfalfa populations was rather strongly differentiated. The least similarity was observed between the inbred F line and the Ulstar variety $(\mathrm{GS}=0.3311)$ (Table 3$)$. The highest similarity was shown by the ecotype 27 and the synthetic population Syn 7-3 (GS = 0.8076). It is worth noticing that the inbred F line has shown to be the least similar to other studied populations.

In the dendrogram of genetic similarity, one can notice distinct clusters combining populations similar from the genetic point of view (Fig. 1) Values of similarity coefficients in these groups are high and they are contained within $0.6718-0.8076$. The first of the clusters includes the Ulstar variety and the ' $t f$ ' mutant. These objects are similar to each other at the level of 


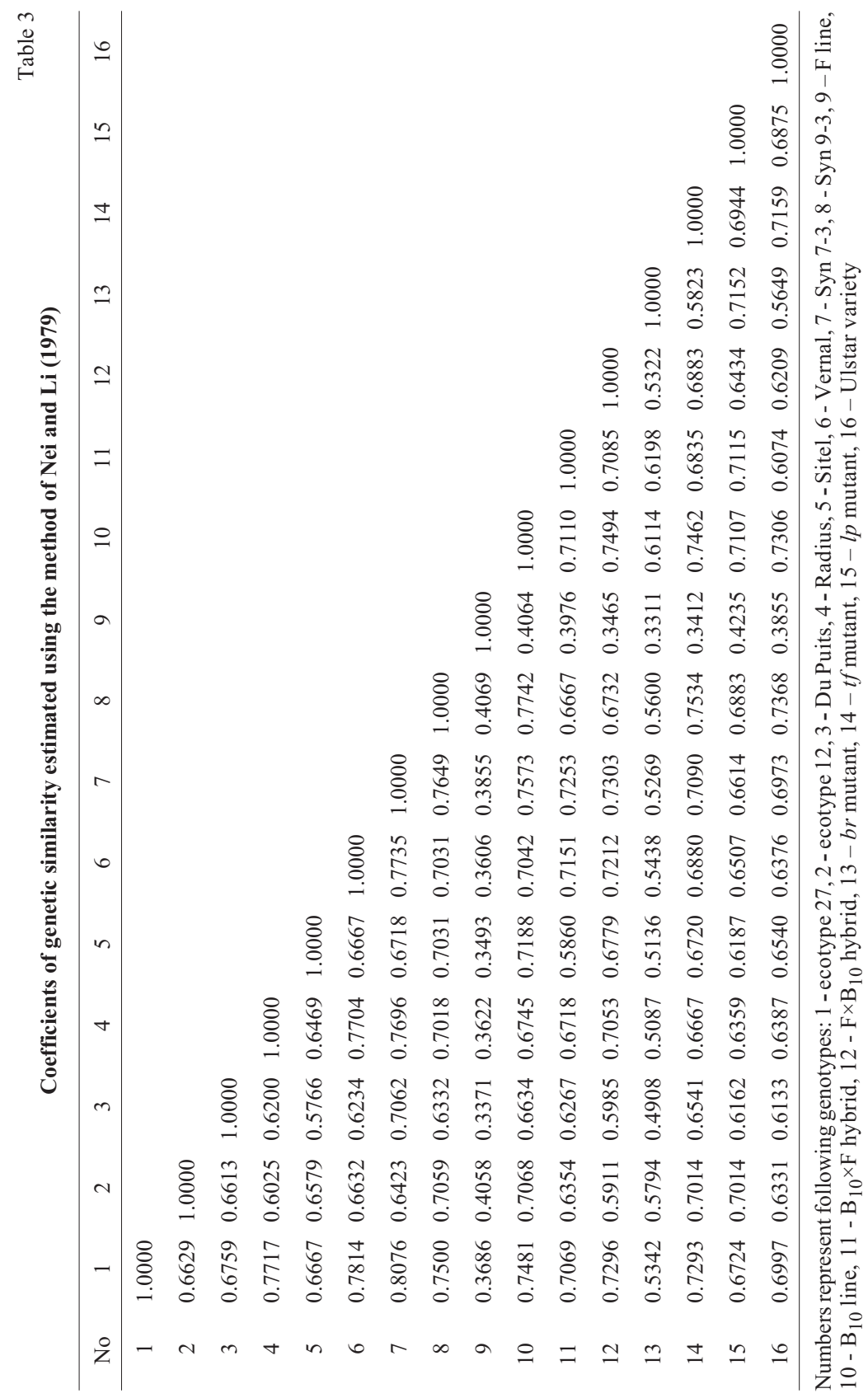


0.7152 . The second cluster is created by mutants ' $b r$ ', ' $l p$ ', population Syn 9-3 and $\mathrm{B}_{10}$ line. The similarity coefficients between these objects range from 0.7159 to 0.7762 . In the third group of similarity, there are the hybrids $\mathrm{F} \times \mathrm{B}_{10}$ and $\mathrm{B}_{10} \times \mathrm{F}$, the varieties Radius and Vernal, ecotype 27 and population Syn 7-3. The values of similarity coefficients between the objects in this group are from 0.6718 to 0.8076 (this value is the highest similarity coefficient observed among the studied objects). The last observable cluster represents a group including the ecotype 12 and the Du Puits variety (GS = $0.6613)$.

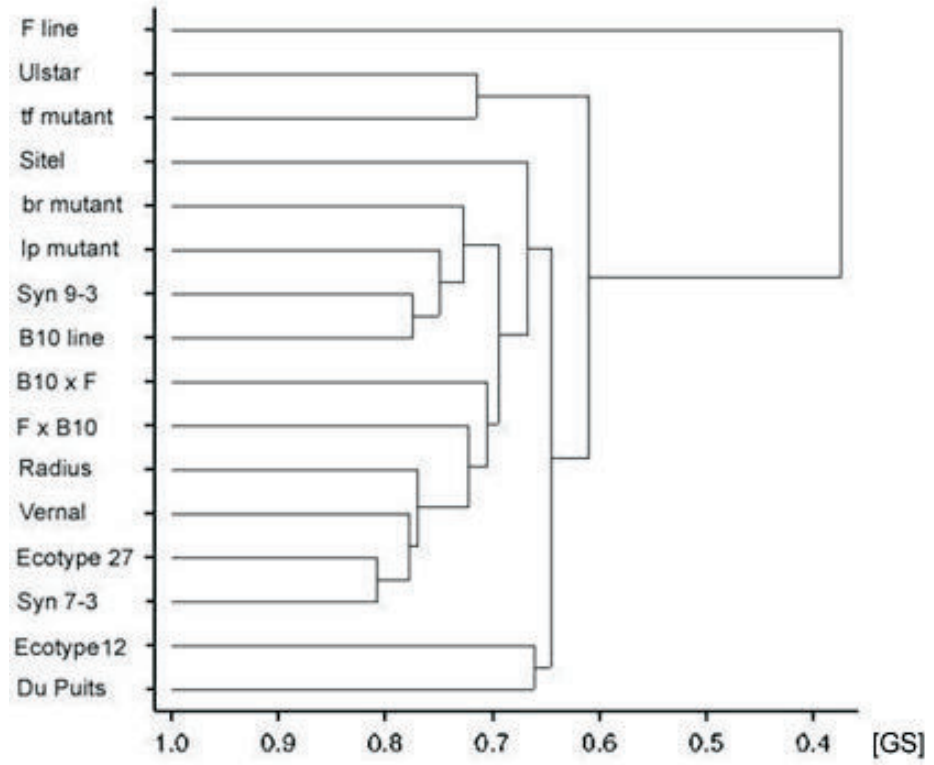

Fig. 1. Dendrogram of genetic similarity [GS] between examinated populations

\section{DISCUSSION}

In the following study, an attempt has been made to estimate the genetic similarity of 16 diversed alfalfa populations by using the AFLP technique. Plant material showed a differentiated origin, it included both the registered varieties, inbred lines, indigenous forms (local ecotypes) and mutants (the studied forms referred to the inflorescence mutations).

10 combinations of primers generating the highest number of polymorphic bands among the 25 tested ones were used. Using them, 12.1 to 29.9 polymorphic bands were obtained (Table 2) per one combination of primers (on the average, for one studied population). It was a smaller number than that obtained by Chen et al. (1999) who used AFLP analysis in orchids and obtained 30-60 bands for each plant. Taking into consideration all used combinations, the mean number of products obtained for one population 
amounted to about 205. This number was also smaller than that obtained by Obert et al. (2000). The latter authors observed about 350 products per one plant in case of alfalfa (also for 10 primer combinations). They also found that the best AFLP pattern was obtained when the primers with four or with three selective nucleotides were applied. In our present studies, primers with 3 selective nucleotides were selected (Table 2). Primers with four selective nucleotides did not give any satisfactory result in case of the analyzed alfalfa populations.

In the presented analysis of alfalfa genetic similarity, bulked DNA samples were used. They were prepared after mixing of the plant material sampled from 10 single plants. The strategies of obtaining bulked samples were initially based on the mixing of equal amounts of genome DNA extracts obtained from single plants. However, an equally effective method consists in the combining of leaf and seed samples (Golembiewski et al. 1997, Kongkiatngam et al. 1996, Sweeney and Danneberger 1995), although in this case, the particular genotypes may not be represented in the sample in equal proportions. In our analyses, collective samples were utilized.

According to the observations made by Kölliker et al. (2001), who carried out a genetic similarity analysis in white clover (Trifolium repens L.), the utilization of collective samples gave in result a slightly simpler profile of bands, in comparison with the profile obtained from single plants of a given variety. They found that about $90 \%$ of products present in the profiles of single plants were present in the profile of a collective sample of a given variety. A definite majority among the products lacking in the collective profile consisted of rarely occurring bands which appeared in less than $25 \%$ of single plants. Furthermore, it was shown that dendrograms made for collective samples and single plants did not differ significantly. Also Michelmore et al. (1991) reported that the combining of DNA samples originating from one object, not only significantly reduces the number of samples necessary for analyses, but it also results in the absence of rarely occurring alleles simplifying thereby the electrophoresis profile of the given variety.

Genetic similarity of alfalfa in the presented studies carried out with the help of AFLP markers oscillated from 0.3311 to 0.8076 (Table 3). These values were similar to those defined by Kölliker et al. (2001) for different varieties of white clover. Those authors found that the genetic similarity between the clover varieties studied by them showed the values from 0.42 to 0.92 .

The following studies have confirmed that AFLP markers can be used to the estimation of alfalfa's genetic distance. An analysis of the genetic similarity dendogram shows that AFLP markers did not group the studied populations in reference to their origin or even phenotype - forms with long peduncle (' $l p$ ' mutant and Ulstar variety) were in different clusters. The values of similarity coefficients between the Ulstar variety, ' $l p$ ' mutant and Radius variety (i.e. components from which it has been created) was 0.6875 
and 0.6387 , respectively (Table 3), although, it could have been expected that these coefficients should be higher. Similar value of genetic similarity between the inbred $\mathrm{F}$ line and the single hybrids $\mathrm{FxB}_{10}$ and $\mathrm{B}_{10} \mathrm{xF}$ was very low, their values were: 0.3465 and 0.4064 , respectively. Equally low value was shown by the coefficients between the synthetic population Syn 9-3 and the inbred $\mathrm{F}$ line (this line constituted one of the components used for the creation of this population) - its value was 0.4069 . However, the similarity between the second of the studied inbred lines $\left(\mathrm{B}_{10}\right)$ and both single hybrids was significantly higher $(0.7494$ and 0.7110 , respectively). The similarity coefficient between that inbred line and the Vernal variety (which was one of the parental components used for its creation) was also high, amounting to 0.7042 . Interesting is, that the $\mathrm{F}$ inbred line differed significantly from other studied objects. It is possible that it resulted from the fact that for the creation of this line, except other components, wild forms of Medicago falcata (yellow-flowered alfalfa) were used, with which none of the other studied populations was related.

\section{CONCLUSIONS}

In the following studies of alfalfa genetic similarity, the highest polymorphism were obtained using combinations of primers with three selective nucleotides.

Examinated populations of alfalfa have not been grouped on the dendrogram of genetic similarity in reference to their origin or even phenotype.

The cause that inbreed line F was the most outlying from the studied populations of alfalfa appears to be its origin - this line was obtained by crossings between $M$. sativa and wild forms of M. falcata.

\section{REFERENCES}

Bachmann K (1994) Molecular markers in plant ecology. New Phytol 126:403-418

Chen X, Lim SH, Wong SM, Lee YH, Kuo J, Yam TW, Lin JJ (1999) Amplified fragment length polymorphism analysis of vandaceous orchids. Plant Science 141:183-189

Golembiewski RC, Danneberger TK, Sweeney PM (1997). Potential of RAPD markers for use in the identification of creeping bentgrass cultivars. Crop Sci 37:212-214

Gustine DL, Huff DR, (1999) Genetic variation within and among white clover populations from managed permanent pastures of the northeastern USA. Crop Sci 39:524-530

Jones CJ, Edwards KJ, Castaglione S, Winfield MO, Sala F, Vandewiel C, Bredemeijer G, Vosman B, Matthes M, Daly A, Brettschneider R, Bettini P, Buiatti M, Maestri E, Malcevschi A, Marmiroli N, Aert R, Volckaert G, Rueda J, Linacero R, Vazquez A, Karp A (1997) Reproducibility testing of RAPD, AFLP and SSR markers in plants by a network of European laboratories. Mol Breed 3:381-390

Julier B, Porcheron A, Ecalle C, Guy P (1995) Genetic variability for morphology, growth and forage yield among perennial diploid and tetraploid lucerne populations (Medicago sativa L.). Agronomie 15:295-304

Kongkiatngam P, Waterway MJ, Fortin MG, Coulman BE (1995) Genetic variation within and between two cultivars of red clover (Trifolium pratense L.) - Comparisons of morphological, isozyme, and RAPD markers. Euphytica 84:237-246

Kongkiatngam P, Waterway MJ, Coulman BE, Fortin MG (1996) Genetic variation among cultivars of red clover (Trifolium pratense L.) detected by RAPD markers amplified from bulk genomic DNA. Euphytica 89:355-361 
Kölliker R, Jones ES, Jahufer MZZ, Forster JW (2001) Bulked AFLP analysis for the assessment of genetic diversity in white clover (Trifolium repens L.). Euphytica 121:305-315

Michelmore RW, Paran I, Kesseli RV (1991) Identification of markers linked to disease-resistance genes by bulked segregant analysis: A rapid method to detect markers in specific genomic regions by using segregating populations. Proc Natl Acad Sci USA 88:9828-9832

Nei M, Li W (1979) Mathematical model for studing genetic variation in terms of restriction endonucleases. Proc. Natl. Acad. Sci. USA 76: 5269 - 5273.

Obert DE, Skinner DZ, Stuteville DL (2000) Association of AFLP markers with downy mildew resistance in autotetraploid alfalfa. Mol Breed 6:287-294

Payne R, Murrey D, Harding S, Baird D, Soutou D, Lane P (2003) GenStat for Windows ( $7^{\text {th }}$ Edition); Introduction. VSN International, Oxford, England.

Rafalski JA, Vogel JM, Morgante M, Powell W, Andre C, Tingey SV (1996) Generating and using DNA markers in plants. In: Birren B and Lai E (Eds.), Non-Mammalian Genomic Analysis: A Practical Guide, Academic Press Inc., San Diego, pp 75-135

Staszewski Z (1975) Lucerny. PWRiL, Warszawa (in polish)

Staub JE, Serquen FC, Gupta M (1996) Genetic markers, map construction, and their application in plant breeding. Hortscience 31:729-741

Sweeney PM, Danneberger TK (1995) RAPD characterization of Poa annua L. populations in golf course greens and fairways. Crop Sci 35:1676-1680

Vos P, Hogers R, Bleeker M, Reijans M, Vandelee T, Hornes M, Frijters A, Pot J, Peleman J, Kuiper M, Zabeau M (1995) AFLP - a new technique for DNA fingerprinting. Nucl Acids Res 23:4407-4414

Yu KF, Pauls KP (1993) Rapid estimation of genetic relatedness among heterogeneous populations of alfalfa by random amplification of bulked genomic DNA samples. Theor Appl Genet 86:788-794 